\title{
Muisti ja ääniympäristöt Euroopan kylissä
}

Huhtikuussa 2000 suomalaisen äänimaisematutkimusryhmämme oli vuoro tutkia pohjoisitalialaista Cembran kylää. Italialainen kollegamme, säveltäjä ja aikasuunnittelija Albert Mayr auttoi meitä järjestämään kylän asukkaille iltatilaisuuden, jossa voisimme kertoa tutkimushankkeestamme ja antautua dialogiin kyläläisten kanssa.

Albert vaati, että illan aluksi on näytettävä dia-kuvia. Nuristen vietin iltapäivän Trenton tuhruisella esikaupunkialueella ja etsin mainostettua 'dioja päivässä' -valokuvausliikettä. Se kannatti: Albert tiesi mistä puhui. Kun seurasimme hänen ohjeitaan ja näytimme muutamia tutkija Noora Vikmanin ottamia dioja, tilaisuuden yleisö - viitisenkymmentä cembralaista pormestari mukaan lukien - huudahteli ja nauroi kuvia katsellessaan. Tämän jälkeen meillä ei ollut vaikeuksia soittaa ääniä ja keskustella tutkimuksestamme.

Noora sai asukkaat jopa mukaan pieniin harjoituksiin. Hän pyysi heitä kuvittelemaan, miltä Cembra mahtaa kuulostaa tulevaisuudessa, 25 vuoden kuluttua. Hetken kuluttua Cembran pormestari, Franco Nardin, nousi tuolistaan ja sanoi kirjanneensa ylös Cembran ääniä, jotka hän haluaisi säilyttää. Äänet olivat: julkisten kaivojen äänet; aukioilla leikkivien lasten äänet; kortinpeluun äänet cantina-viinikellareissa; italialaisen perinteisen ruoanlaiton äänet (myös katoamassa olevien uunien) sekä inhimillinen verbaalinen kommunikaatio kaupoissa.

Nardinin mainitsemat äänet kuuluvat perinteisissä sosiaalisissa tilanteissa ja paikoissa. Sosiaalisuuden paikat ja muisti liittyvät lähtemättömästi yhteen: ns. generatiivinen muisti (ks. Candau 1996, 49) kukoistaa piazzojen, kahviloiden ja pyykinpesukaivojen tapaisissa paikoissa. Tämän kirjoituksen keskeisiä aiheita ovatkin ääni ja muisti. Aluksi pohdin lyhyesti kollektiivista muistia. Kerron tutkimushankkeesta 'Ääniympäristöt muutoksessa', jota parhaillaan vedän ja kuvailen hieman kutakin

${ }^{1}$ Tämä artikkeli pohjautuu kesäkuussa 2000 Kanadassa, World Forum of Acoustic Ecology -konferenssissa 'Sound Escape' pitämääni keynote-esitelmään 'Place, Memory and Acoustic Environments: Five European Villages Revisited'. Kiitän Taru Leppästä, Jukka Sarjalaa ja Kimmo Miettistä kommenteista. 
tutkimuksen kuutta kohdekylää, muistiteeman muistaen. Poimin yhden kylistä, eteläsaksalaisen Bissingenin, tarkemman kuvauksen kohteeksi. Lopuksi tuon vielä esiin aspekteja muistin ja äänen tutkimuksesta.

\section{Kollektiivinen ja sosiaalinen muisti}

Muisti on yleisinhimillinen: ilman muistia ei olisi olemassa yksilö- eikä ryhmäidentiteettejä eikä oikeastaan mainitsemisen arvoista sosiaalista elämää ylipäätään. Maurice Halbwachsin 1900-luvun alkuvuosikymmeninä kehittämä käsite 'kollektiivinen muisti' on hyödyllistä tuntea, jos on kiinnostunut sosiaalisen ja muistin yhteyksistä. Halbwachs väitti, että ryhmäidentiteetit muodostavat muistin perustan: yksilö muistaa lapsuutensa perheen osana; naapurinsa paikallisen yhteisön osana; työelämänsä tehdas- tai toimistoyhteisön osana. Kollektiivisen muistin käsitettä käytetään ja siitä kiistellään yhä. (Halbwachs 1925; 1950; Fentress \& Wickham 1992, vi.) Käytin itsekin käsitteestä johdettua sosiaalisen muistin ajatuskehikkoa, kun laadin tutkimusprojektini haastattelukysymyksiä ihmisten äänimuistoista.

Tämän lähestymistavan ongelmallisin kohta, seikka jota Halbwachs ei pystynyt tyydyttävästi ratkaisemaan, oli yksilömuistin suhde kollektiiviseen muistiin. Loppujen lopuksihan ainoastaan yksilöt voivat muistaa. Muistin antropologi Joel Candauta (1996, 63-64) seuraten voimme kaikessa rauhassa myöntää, että on olemassa ihmisyhteisöille ominaisia muistamisen kokonaisuuksia, mutta näiden konfiguraatioiden sisällä jokaisella yksilöllä on omat muistamisen tapansa, jotka riippuvat hänen ainutlaatuisesta menneisyydestään, yksilökehityksestään sekä omasta erityislaatuisesta hermojärjestelmästään. Kollektiivinen muisti ei ole yksiääninen - se on aina erilaisten keskenään risteilevien, jopa toisilleen vastakkaisten muistien työn tulosta.

Erityisen kiinnostavia tutkimusaiheita suhteessa äänimuistojen sosiaaliseen tutkimukseen ovat: perheiden ja eri sukupolvien äänimuistot; äänimuistojen yhteys kalendaarisiin ja vuodenaikojen rytmeihin; kollektiivinen huonomuistisuus tai muistinmenetys sekä äänimuistojen ulkoistaminen. Viittaan näihin kuhunkin, kun jatkossa kerron tutkimistamme eurooppalaisista kylistä.

\section{Ääniympäristöt muutoksessa -tutkimusprojekti}

Suomalainen tutkijaryhmä tutki kevään 2000 aikana kuuden eurooppalaisen kylän äänimaisemia. Tutkimus seuraili 25 vuotta sitten Euroopassa Volkswagen-bussilla 
kiertäneen kanadalaisen tutkimusretkikunnan jalanjälkiä. Tuolloin neljä World Soundscape -hankkeen jäsentä perehtyi maaseutukylien äänimaisemiin ruotsalaisessa Skruvissa, eteläsaksalaisessa Bissingenissä, pohjoisitalialaisessa Cembrassa, bretagnelaisessa Lesconilissa ja skotlantilaisessa Dollarissa. Tutkijat tarkastelivat erityisesti äänten suhdetta kunkin kylän sosiaaliseen, kulttuuriseen ja luonnonympäristöön. (Schafer 1977a; Schafer 1977b.)

Suomalaiset tutkijat ovat palanneet näihin kyliin kartoittamaan äänimaisemien muutoksia. Yhtenä lähtökohtana on se seikka, että ääniympäristöllä on olennainen vaikutus ihmisten ja muidenkin elollisten hyvin- ja pahoinvointiin. Äänet ovat myös tärkeitä sekä vuorovaikutuksen että paikallisidentiteettien kannalta. Varsinaissuomalainen saaristokylä Nauvo (Nagu) on lisätty mukaan tähän Suomen Akatemian rahoittamaan hankkeeseen.

Tämä tutkimus tarjoaa mahdollisuuden tehdä vertailevaa tutkimusta eurooppalaisten äänimaisemien muutoksesta. Yksi tavoitteistamme on hyödyntää nykytietoa ja siten kehittää akustisen ekologian käsitteitä ja metodeja. Tutkimuksen seuraavassa vaiheessa on tarkoitus tehdä yhteistyötä myös paikallisten yhteiskuntasuunnittelijoiden ja arkkitehtien kanssa ja siten dialogissa heidän kanssaan kehittää paikallisten äänimaisemien suunnittelun työkaluja.

Päätutkimusryhmään kuuluu kolme jatko-opiskelijaa. Noora Vikman (TaY) tutkii ääniympäristöjä ja paikallisidentiteettejä Cembrassa ja Bissingenissä, Heikki Uimonen (TaY) akustista kommunikaatiota Skruvissa ja Dollarissa. Tero Hyvärisen (TY) mielenkiinnon kohteena on ympäristöestetiikan käsitteiden soveltuvuus äänimaisematutkimukseen; kenttätyön kohteena hänellä on Nauvo. Lisäksi useiden maiden tutkijoita on osallistunut työhön, ja kanadalaiset alan pioneerit ovat auliisti auttaneet meitä. Mukana on ollut myös taideopiskelijoita Tampereen Ammattikorkeakoulun Taiteen ja Viestinnän osastosta sekä ammattitaiteilijoita ja toimittajia. Tärkein kenttätyöperiodi kesti vuoden 2000 kevään ajan. Tätä kirjoitettaessa se siis päättyi runsas kuukausi sitten. Näin ollen en tietenkään voi vielä tarjota tarkkoja tuloksia tai analyyseja tutkimusaineistosta. Sen sijaan voin kertoa kenttävaikutelmistani ja tarjota eväitä tai ainakin eväidenpäällisiä tuleviin analyyseihin.

Koska halusimme tutkia muutosta, yritimme kenttätyössämme tietyin osin seurata World Soundscape -projektin menettelytapoja: järjestimme äänikävelypäivän, laskimme liikennettä ja teimme kouluissa Sound Preference -testin. Äänikävelypäivänä kylän asuma-alueet jaettiin viiteen osaan. Jokainen alue sai oman kuuntelijansa: tutkija käveli viisi puolen tunnin jaksoa alueella tiettyinä kellonaikoina ja merkitsi muistiin kaiken kuulemansa. Aiemmassa tutkimuksessa äänikävelyt raportoitiin lähinnä kvantitatiivisina listoina. Tällä kertaa yritimme varmistaa, että myös subjektiiviset kuuntelemisen tavat ja äänten kontekstit kirjattiin ylös.

Liikenteenlaskenta saattaa kuulostaa ikävystyttävältä ja aataminaikuiselta määrälliseltä metodilta. Tutkija oppii kuitenkin yllättävän paljon kylien elämästä, kun hän 


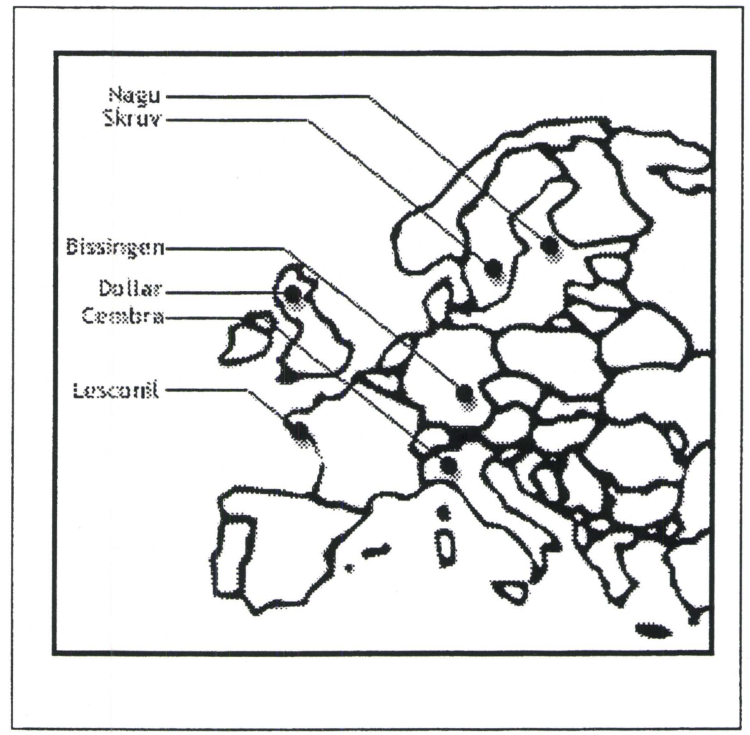

Ääniympäristöt muutoksessa -projektin kylät. Kuvalähde: http://www.6villages.tpu.fi/

seisoo kylän keskeisellä paikalla ja laskee, kuuntelee ja tarkkailee ihmisten puuhia, mitä kulkuvälineitä he käyttävät liikkuessaan paikasta toiseen, millaisia ovat liikkujien sukupuoli- ja ikäjakaumat eri vuorokaudenaikoina. Metodi liittyikin vuonna 1975 tutkimustehtävään, jossa kylän sosiaalisia ja elinkeinoihin liittyviä rytmejä verrattiin äänten rytmeihin, ja menetelmä on edelleen käyttökelpoinen. Kolmas suoraan lainattu metodi oli Sound Preference -testi kunkin kylän koulussa: lapset tai nuoret saivat listata itselleen miellyttävimmät ja epämiellyttävimmät äänet. Paikallisten tutkijoiden avulla (esimerkiksi Claudio Lagomarsini Cembrassa, Gregg Wagstaff Dollarissa ja Nicolas Tixier Lesconilissa) teimme myös ääniharjoituksia lasten kanssa ja keskustelimme heidän kanssaan.

Tässä yhteydessä en syvenny kertomaan kehittämistämme uusista metodeista: mainitsen vain, että kirjoitutimme kylissä äänipäiväkirjoja. Uutta tässä oli se, etteivät vain tutkijat kirjoittaneet niitä (ks. Schafer 1977b), vaan myös koululaiset sekä eri ikä- ja ammattiryhmiä edustavat muut kyläläiset. Tämän kirjoituksen muistiteeman kannalta haastattelut olivat oleellisia. Niitä tehtiin kaikissa kylissä, omin voimin ja tulkkien avustuksella. Emme voineet käyttää haastatteluissa äidinkieltämme juurikaan edes suomalaisessa kylässä, sillä Nauvo sijaitsee suomenruotsalaisella kielialueella. 


\title{
Kyliä, kuvauksia, äänimuistoja
}

\section{Skruv}

Smålantilainen Skruv sijaitsee Kaakkois-Ruotsissa. Alue tunnetaan lasitehtaistaan, mutta myös metalli- ja puuteollisuus sekä panimo työllistävät kyläläisiä. Junat eivät enää nykyisin pysähdy asemalla, joka kerran oli tärkeä seisakki itäisen Kalmarin ja läntisen Göteborgin välisen rautatien varrella. Silti kylän ohitse suhahtavat pika- ja tavarajunat vaikuttavat omalla tavallaan kylän äänimaisemaan. (Ks. Uimonen 2000b.)

Kun World Soundscape -projektin jäsenet kävelivät vuonna 1975 helmikuisen Skruvin kylmiä katuja, he kuulivat, kuinka kaupunki soitti kulkijoille melodioita, "sähköisen vallankumouksen kansanmusiikkia" (Schafer toim. 1977, 12). Jokainen tehdasrakennus nimittäin humisi omalta tietyltä sävelkorkeudeltaan. Helmikuussa 2000 kuulimme tehtaiden sävelet selkeästi:

\begin{abstract}
Panimo lauloi tänä aamuna erityisen kauniisti ja selkeästi. Nautiskelin sen äänestä ja mietin, että se olisi saatava DAT:ille. (--) Siinä on jotain vihellyksentapaista. Alin sointu oli riitasoinnissa ylemmän kanssa. Panimolla on siis aivan oma sointunsa. Tuuli. Mahtoiko tuuli voimistaa ääntä? (--) Välillä arvelin, että salissa soitetaan musiikkia. Mutta turhan yksitoikkoiselta se kuulosti, aina sama sointu. (ÄPK HJ, 7.2.2000, 3.)
\end{abstract}

Tehtaiden huminat olivat säilyneet, mutta 25 vuoden takaiset tärkeät äänisignaalit, tehtaanpillien vihellykset, olivat sen sijaan tyystin hävinneet. Kyselimme Skruvissa monilta asukkailta, koska vihellykset olivat hävinneet. Vastausten kirjo ulottui 1960-luvun alusta 1990-luvulle saakka. Itse asiassa pillit pysäytettiin, kun panimo meni konkurssiin vuonna 1981. Kun se pian avattiin uudelleen, pillejä ei enää käytetty.

Onkin mielenkiintoista luodata unohtuneita ääniä ja kollektiivista huonomuistisuutta $^{2}$. Ryhmät ja yhteisöt rakentavat identiteettejään yhtä lailla unohtamisen kuin muistamisen perustalle. (Ks. Candau 1996, 5.) Tehtaanpillien tapaus osoittaa, että tietoisuutemme muistamisen ja itse tapahtuman välissä vierähtäneen ajan pituudesta vaihtelee. Gaston Bachelard (1950) on todennut, ettei sielumme pidä lukua matkastamme ajan halki. Muistamme vain tapahtumat, jotka osuvat elämämme tärkeimpiin periodeihin.

Menneisyys on aina osa ihmisten nykyisiä pyrkimyksiä. Tehtaanpillien vihellykset edustavat skruvilaisille 'menneitä aikoja'. Monet haastateltavat kommentoivat, etteivät he enää tarvitse pillejä: onhan kellokortit keksitty. Korkeintaan juuri ennen kesälomia joku veijari saattaa löytää panimon pillin nappulan ja painaa sitä. Siten

2 Joel Candau puhuu kollektiivisesta huonomuistisuudesta, mutta hyvin perustein voitaisiin puhua myös toisin muistamisesta. 
pillit saavat myös edustaa aikaa, jolloin työ ja vapaa-aika erottuivat tiukemmin toisistaan. Nyt ihmiset sanoivat, että tehdastyö on tullut huomattavasti pakkotahtisemmaksi ja tauot ovat lyhentyneet.

\section{Cembra}

Vuonna 1975 kanadalaistutkijat ylistivät pohjoisitalialaisen vuoristokylä Cembran äänimaisemaa. Se oli heidän mielestään ehdottomasti inhimillisin kaikista tutkituista viidestä kylästä. Cembran äänet olivat edelleen inhimillisiä, etenkin vanhassa kaupunginosassa, jonka kiviset, osin keskiaikaiset seinät heijastelivat ääniä sinne tänne. Kylä sijaitsee vastakkaisten vuorenrinteiden katveessa. Rinteet ovat liian jyrkkiä laskettelutarkoituksiin, joten kylän turistitoimisto saa tehdä töitä houkutellessaan turisteja paikkakunnalle. (Ks. Vikman 2000.)

Kylän väkiluku on kuitenkin kasvanut ja kokonainen iso asuinalue on rakennettu kylän pelloille. Uuden ja vanhan osan lävitse johtaa vilkasliikenteinen tie yhtäältä Trenton kaupunkiin, toisaalta edemmäksi vuorille. Neljännesvuosisata on lisännyt kylän vaurautta melkoisesti. Siellä louhittu profido-kivi on noussut arvoon arvaamattomaan. Kuten lapsia tien yli ruuhka-aikoina kouluun suojatietä saatteleva eläkeläismies totesi, vauraus tuo lisää melua. (Ks. myös Schafer toim. 1977, 80.)

Töykeä (liikenteen)laskentahetki: kamalasti porukkaa ja autoja. Naisia (ja yksi mies) seisoi Lavis'iin (ja Trentoon) menevällä bussipysäkillä, miehiä vastakkaisessa kadunkulmassa. Naisia ei ollut siellä yhtään. Heitä juoksi bussiin, joka seisoi tyhjäkäynnillä minuuttikaupalla, koko ajan. Miehet nousivat pienissä porukoissa eri pakettiautoihin, kimppakyydeiltä vaikuttivat.(--)

Niin - (kirkon)kello moukutti pitkään, seitsemän lyöntejä. Se lienee se virallinen herätyshetki. Puhuimme Kimmon kanssa kellon ajanilmoitussaundista: Kimmo tosiaan oli luullut sitä hotellin kaappikelloksi. Minustakin ääni muistuttaa suomalaista kaappikelloa. Sitä ei ole siis tarkoitettukaan pyhäksi, vaan ajanilmoittajaksi.

Silti: ei seitsemän lyöntirupeama ollu heleä eikä kumea. Soundi on-peltinen. Lintujen laulun sulo on jo kadonnut. Raskas aamuliikenne on peittänyt sen alleen. Vain vahvat äänet elävät.

(ÄPK HJ, 18.4.2000 klo 7.20.)

Yhteys vaurauden ja melun välillä tuli ilmi myös Cembran vuodenaikojen äänirytmeistä puhuttaessa. Lähes jokainen kyläläinen oli sitä mieltä, että tyypillinen syksyn ääni on traktorien jyminä, kun ne jonottavat viinirypälelastissa osuuskunnan omistamaan viinitehtaaseen, jonka majesteettinen rakennus hallitsee kylän keskiosaa.

Cembrassa perheet keräsivät kaikenlaisia muistoja, eivät vain valokuvia ja käsikirjoituksia vaan myös äänellisiä muistoja. He säilyttivät vanhoja soittimia ja työkaluja omissa viinikellareissaan ja baita-vuoristomajoissaan. Näitten ääniä esiteltiin meille tutkijoille innolla. Tämäntyyppiset äänimuistot ylittävät sukupolvien rajat: ne ovat suvun muistoja, jotka vahvistavat suvun jatkuvuutta kylässä. 
Yksi muistin tyypillinen piirre on, etteivät ihmiset muista tapahtumia niinkään vuosilukujen - ulkoapäin pakotetun kronologian - kuin oman henkilökohtaisen tai perheensä historian kautta (Candau 1996, 51-55). Huomasin tämän mm. silloin, kun kyselin vaikkapa ensimmäisen television ostamisesta kylään. Asukkaat muistivat tapahtuman suhteuttamalla sen ajankohtaan, jolloin he muuttivat tiettyyn taloon, jolloin heille syntyi lapsia jne. - näin jopa silloin, kun muistelija oli kodinkoneliikkeen omistaja, kuten oli laita seuraavassa, Lesconilin kylässä.

\section{Lesconil}

Lesconil on kalastajakylä Bretagnessa, läntisessä Ranskassa. Sen 1500 asukkaan väkiluku tuplaantuu kesäaikana, kun hiekkarannat houkuttelevat turisteja. Kalahuutokaupan ääniä voi kuulla päivittäin klo 16.30, jolloin päivän saalis myydään. Kalastajien erikoisaluetta ovat keisarihummerit. (Ks. Järviluoma 2000.)

Kalastaja-alusten määrä on kuitenkin merkittävästi vähentynyt: vuonna 1975 niitä oli viisikymmentä, 25 vuotta myöhemmin ainoastaan viisitoista. Tämä on todellinen ongelma, kalastus kun ruokkii muitakin elinkeinoja. Esimerkiksi turistit tulevat Lesconiliin paljolti kalastajien ja pittoreskien kalahuutokauppojen perässä. Tankkeri Erican onnettomuus Bretagnen edustalla on myös vaikuttanut sekä ympäristöön että turismiin, vaikkakin asian ympärillä tuntui keväällä 2000 vallitsevan kollektiivinen muistinmenetys. Ihmiset saattoivat kieltää onnettomuuden vaikutukset kaloissa täysin, vaikka öljyä saattoi joskus nähdä niiden pinnalla jo paljain silmin.

\section{Nauvo}

Nauvo sijaitsee Suomen lounaissaaristossa. Nauvolaisista noin $70 \%$ puhuu äidinkielenään ruotsia. Paikallinen elinkeinoelämä pohjautuu turismiin, maanviljelykseen, palveluammatteihin ja kalastukseen. Tielaitoksen lautat hoitavat tieliikenneyhteydet Paraisille ja sitä kautta mantereelle. Nauvoa ja Lesconilia yhdistää paitsi meren läheisyys myös se seikka, että vuodenaikojen rytmit muokkaavat suuresti äänimaisemia. (Ks. Hyvärinen 2000.)

Sanotaan, että Nauvon 1500 asukkaan väkiluku nousee jopa 10000 kesäkuukausien aikana - ei toki kirkonkylän, vaan kuntaan kuuluvien saarten kokonaisuudessaan. Jotkut haastatelluista pystyivät kuvaamaan vuodenaikojen vaihtelut hyvin eloisasti. Kulttuuriasiainhoitaja Christine Bång kuvaili, miltä Nauvo kuulosti 1950luvulla eri vuodenaikoina, miltä taas vuonna 2000. Kalendaariset ja vuodenaikojen rytmit solmiutuvat kollektiivisiin äänikokemuksiin ja -muistoihin. Samaa ilmiötä on tutkittu myös muiden aistien, esimerkiksi hajumuistojen yhteydessä (Roubin 1989; Candau 1996, 123).

\section{Dollar}

Seuraavassa tutkimuskylässämme, skotlantilaisessa Dollarissa säkkipilliyhtyeiden 
ulkoilmaharjoitukset ovat pitkään olleet kesän merkkejä. Dollar sijoittuu ItäSkotlantiin Clackmannnanshiren maakuntaan ja nykyisin siellä asuu liki 3000 ihmistä. Kuuluisa, lähes 200 vanha yksityiskoulu Dollar Academy kuuluu ja näkyy selvästi kylän elämässä: koululaiset univormuissaan täyttävät pääkadut koulumatkoillaan ja lounastauoilla. (Ks. Uimonen 2000a.)

Tänä vuonna Dollarin museon edustajat valokuvasivat Millenium-projektina kaikki Dollarin rakennukset. Kuvat on tarkoitus laittaa aikakapseliin museon ullakolle; siten niistä tehdään "keinotekoisesti" arvokkaampia. Nyt on käynnissä keskustelu, mitä muuta materiaalia aikakapseliin pitäisi laittaa ja pitäisikö sitä pitää suljettuna 50 vai 100 vuotta.

Kollegamme Gregg Wagstaff, joka on avustanut projektissamme, on pohdiskellut olisiko syytä laittaa kapseliin myös Dollarin ääniä. Hän on varmaankin oikeassa siinä, että jos mukaan laitetaan DAT- tai MD-levyjä, on syytä pistää mukaan myös nauhurit - 50 vuoden kuluttua nämä laitteet lienevät harvinaisia.

Tässä törmäämme mielenkintoiseen kysymykseen: äänimuistojen ulkoistamiseen. Jo nauhoituksia tehdessämme ulkoistamme muistoja. Sosiaalista muistia tutkineet Fentress ja Wickham ovat huomauttaneet, että ehkä kaikessa hiljaisuudessa ryhdymme pitämään muistia esineenä, kun innolla keräämme muistoja ja kokoamme niitä suullisen perinnön arkistoihin. $(1992,64$.) Toisaalta ulkoistetut muistot voivat vallan hyvin tukea sosiaalista muistia, koska ne usein kiertävät yhteisön asukkaiden käsissä ja siten tukevat suullisia traditioita.

Tässä tulemme tärkeään kysymykseen dialogisesta kenttätyöstä (ks. Järviluoma 1991). Se seikka, tukevatko ulkoistetut äänimuistot paikantunnon rakentamista, paikkaidentiteettejä, riippuu kyvystämme asettua dialogiin tutkittavien ihmisten kanssa.

\section{Tapaus Bissingen - ammatit muuttuvat, äänet muuttuvat}

Kaksikymmentäviisi vuotta sitten Bissingeniin saapuneet kanadalaistutkijat huomasivat heti tulleensa maalaiskylään. Useiden kylän talojen edessä kasvoi melkoinen lantakasa - schwaabialaisen talonpojan vaurauden tunnusmerkki. Alb-vuorten pohjoisimpien rinteiden väliin jäävässä laaksossa, 35 kilometriä Stuttgartista etelään sijaitsevassa kylässä oli tuolloin vielä 40 maanviljelijää. Nykyisin heitä on enää kolme tai neljä. Kylän harvat lehmät eivät enää ammu ulkolaitumilla kesäisinkään, sillä ne pidetään navetoissaan ympäri vuoden.

Kylän rakennustyyliin ovat vanhastaan kuuluneet jyrkkälappeiset talot, joiden keskellä on navetta ja asunto ja varastot sen sivustoilla. Nykyisin 'navetoista' kuuluu useimmiten autojen hurinoita. (Ks. Vikman 2000a.) Elinkeinorakenteen muutoksella on muutenkin ollut huomattava vaikutus äänimaisemaan. Vuonna 2000 
kylässä on 3600 asukasta ja työikäisistä jopa 1700 ajaa päivittäin työn perässä Bissingenin ulkopuolelle: etupäässä Stuttgartiin, Kirchheimiin tai muihin isompiin kuntiin.

Kotitarveviljelijöitä, hedelmäpuutarhureita, kanan- ja lampaankasvattajia kylällä toki vielä on. Lantatunkiotkin kukoistavat komeina kymmenien talojen edessä. Lapsuudenkyläänsä Stuttgartin lentokentän läheltä muuttanut biologi Heinz Reinöhl totesikin, että hän herää vaimoineen mieluummin kukkokiekuuhun kuin lentokoneiden ääneen: kukot herättävät kuudelta toinen toisensa ja siinä sivussa ihmiset.

Lausunto on siinä mielessä mielenkiintoinen, että Bissingen sijaitsee keskeisten lentoreittien aluella, ja lentokoneiden jylinät kuuluvat kylään lähestulkoon taukoamatta. Samoin oli asian laita vuonna 1975, mutta yksi tärkeä ero löytyi: Tero Hyvärisen mittausten mukaan lentokoneiden melu on nyt vaimeampaa eli desibeliluvut ovat jopa kymmenen desibeliä alhaisempia. Osasyynä tähän on sotilaslentojen väheneminen. Ihmiset tuntuivat tottuneen lentokoneiden ääniin. Vain harvat valittivat, että jetit keskeyttävät lintujen konserttien kuuntelun.

\section{Liikenteen äänet hallitsevat pääkadulla}

Autoliikenteen ja sen aiheuttaman hurinan ja rengasmelun määrä sen sijaan on huomattavasti kasvanut kylän sisällä. Jo kaksikymmentäviisi vuotta sitten Bissingen ja Dollar kuuluivat tutkituista kylistä autovaltaisimpiin. Nyt autoja kulki kiivaimpina aikoina kylän päätiellä jopa puolta enemmän kuin tuolloin. Yksi syy tähän on se, että kylän toiselle laitamalle on, nerokasta kyllä, rakennettu iso asuinalue, jonne päästäkseen on ajettava vanhan keskustan halki.

Elämisen rytmit kuuluvat eri kylien liikenteen äänissä aivan selvästi: Bissingenissä ruuhkaa oli kaukotyöläisten ja koululaisten työmatka-aikoina ja puolenpäivän jälkeisellä lounastauolla. Kyläläiset valittivat sitä, etteivät ihmiset jaksa enää kävellä pieniäkään matkoja: "mitä koululaisille on tapahtunut, kun vanhempien pitää tuoda ja hakea heidät puolen kilometrin päästä koulusta?"3 Nuoriso ottaa keskustan tilan äänellisesti haltuunsa myöhään perjantai-iltana, kun muu mekkala on vaimennut ja saa näin ansaittua huomiota.

\footnotetext{
${ }^{3}$ Autot olivat ottamassa valtaa kävelijöiltä myös Cembrassa, joten pormestarin huoli lasten leikin äänien katoamisesta piazzoilta oli aito. Aukiot olivat jo autojen täyttämiä. Ihmiset liikkuivat muutaman sadan metrin matkan kaupunginosasta toiseen usein autolla. Arkkitehdit puhuvat luontevasta aistivan ihmisen liikkumisnopeudesta: se on $5 \mathrm{~km}$ tunnissa eli kävelynopeus. Cembran tiheää kapeakatuista kiviarkkitehtuuria ei ole tarkoitettu $50 \mathrm{~km}$ tuntinopeudella aistittavaksi. Dollarissa tilanne oli vielä kärjistyneempi. Hotellimme omistaja päivitteli, että kun ihmiset tulevat autolla pubiin perjantaina, he ottavat myöhemmin illalla taksin kotiin kilometrin päähän. Aamulla mies saattaa tulla vaimon ja kakkosauton kanssa hakemaan ensimmäistä autoa. Koko kylän päästä päähän kuitenkin kävelee muutamassa kymmenessä minuutissa.
} 
Kylän keskelle, raatihuoneen edustalle laitettiin 80-luvulla katukiveys. Pormestarin mielestä se oli aivan turhaa hienostelua ja lisäksi se lisäsi keskustan liikenteen ääntä melkoisesti. Kaupunginvaltuusto onkin päättänyt, ettei lisää kiveyksiä enää laitella. Pienen keskusaukion suihkulähdettä ei hurinalta kuule arkiaamuina seitsemän jälkeen. Äänet peittyvät puuroksi, lo- $f$-äänimaisemaksi.

Sivummalla sijaitsevilla asuinalueilla vallitsee kuitenkin selkeä $h i-f i$-äänimaisema. Äänet erottuvat hyvin toisistaan: kurdilasten riemukas leikkiminen, saksalaismiehen kiljuminen, kun hän ajaa heitä rauhaa rikkomasta leikkikentälle, pianonpimputus talon sisältä, nikkaroinnin sekä omena- ja kirsikkapuiden oksimisen äänet. Äänimaisema muuttuu, kun joku innostuu käyttämään moottorisahaansa asuinalueen lähistöllä päivät pääksytysten.

\section{Äänimuistikuvien metsästystä}

80-vuotias edelleen majataloa emännöivä Else Ederle ilmeni varsinaiseksi korvintodistajaksi. Hän puhui monista äänimuistoistaan: $\mathrm{mm}$. Stuttgartin pommitusten painajaismaisista äänistä, jotka tärisyttivät taloja Bissingenissä asti. Monet toisen maailmansodan aikana eläneen sukupolven ihmiset jakavat pommitusäänten muistot. Lesconilissa tapasin merimiehen, jonka koskettavimmat äänimuistot liittyivät Brestin pommituksiin. Sodan äänet ovat esimerkki tiettyjen sukupolvien äänimuistoista Länsi-Euroopassa.

Else Ederlen 1600-luvulla rakennetun Lamm-majatalon viereisen vanhan kaivon lorina on porautunut hänen muistiinsa: kun katua viemäröitiin ja kaivon ääni katosi päiviksi, Ederle ei saanut unta. Kun ääni palasi, myös unenlahjat palasivat. Ääni oikeastaan usein tiedostetaankin vasta kun se on poissa.

Mitä jo kadonneita ääniä bissingeniläiset sitten kaipasivat? Jo mainittu biologi Reinöhl ei sanonut tiedostaneensa ollenkaan, että oli kaivannut Bissingenin kellojen ääntä, ennen kuin muutti kylään takaisin. Maanviljelijä Hans Ederle taas kertoi, että hänen mielestään viikatteen ääni aamukasteisella pellolla oli hyvin kaunis ääni, joka on hävinnyt. Kun kysyin, kaipasiko hän tätä ääntä, hän kielsi jyrkästi: 'Tämä on nostalgiaa." Myös suomalaiset maanviljelijät kiirehtivät useimmiten tähdentämään, että lukuisten maatalouskoneiden ääni on siunattua melua (Pöyskö 1995); aivan samoin Hans Ederlen mielestä niittokone helpottaa niin paljon hänen työtään, ettei hän halua viikatetta takaisin. 


\section{Monet tarinat kirkonkelloista}

Kirkonkellot ja niiden äänet kirvoittavat ihmiset eri kylissä kertomaan monenlaisia tarinoita. Lesconilin kalastajakylässä tutkijoille kerrottiin 1970-luvulla, että kellonsoittaja saattoi soittaa kelloja hyvinkin pitkään kylän kommunistien kiusaksi. Skruvilaiset olivat työlääntyneitä tuoreisiin, 1990-luvun alussa asennettuihin kelloihinsa, jotka heidän mielestään moukuttivat aivan liian kovaa ja rumalla äänellä. Kylän urkurin haastattelu paljasti, että kelloja valettaessa oli säästetty rahaa ja näin saatu esteettisesti epätyydyttävä lopputulos.

Bissingenin kirkonkellot ovat edelleen seudun ehdoton äänimaamerkki - kylän identiteetille tärkeä ääni. Ne soivat saksalaiseen tapaan usein, viidentoista minuutin välein, ja sointi on heleä. Neljä kertaa päivässä ne soivat pidempään: herättävät rukoukseen, kutsuvat ruokailuun, muistuttavat Kristuksen kuolinhetkestä kolmelta ja hiljentävät iltaan.

Kellot soivat edelleen yhtä kovaäänisesti kuin vuonna 1975. Kartoitimme kirkonkellojen niin sanotun akustisen profiilin: kuinka kaukana kylästä kellot eri ilmansuunnissa voitiin kuulla. Ennenaikaanhan yksi kirkonkellojen tehtävistä oli määritellä seurakunnan laajuutta. Havaintojemme ja kyselyjemme mukaan kellojen profiili oli säilynyt ennallaan ellei jopa laajentunut. Teoria siitä, että kirkonkellot kuultaisiin yhä pienenevän kehän sisäpuolella ei siis näytä pitävän paikkaansa.

Kellot vaihdettiin vuonna 1969 ja tästä seurasi armoton jupakka, josta kyläläisten kertoivat vieläkin erilaisia tarinoita tutkija Noora Vikmanille, kuten he kertoivat tutkijoille jo vuonna 1975. Kyläläisten mielestä oli luvattu, että kellot valetaan entisistä, joilla oli heille huomattavaa tunnearvoa. Uudet kellot olivat jo tornissa, kun kyläläiset äkkäsivät vanhat rakkaat kellot kirkon alakerrassa. Kylän nuori pastori kertoi meille, että hänen tietonsa mukaan oli sovittu vain, että vanhaa sarjaa voi käyttää uuden maksuun.

Kyläläiset kuitenkin sydämistyivät niin, että hurjistunein varasti pienimmän kellon, juoksi hurjaa vauhtia kylän läpi ja paiskasi sen järveen. Kirkkoneuvosto naarasi sen sieltä vähin äänin ja vei sulattamoon muiden seuraksi. Toisen Noora Vikmanin kuuleman version mukaan taas eräs kyläläinen panttasi kelloa kotonaan vuosikaudet, ennen kuin synnintunnossa palautti sen. Oli miten oli, vuonna 1970 kyläläiset saivat neljännen kellon sovintolahjaksi. Siinä lukee: 'Rauha olkoon teidän kanssanne'. Pappi kylläkin erotettiin.

Tarinat ovat muistin luontaisia apuvälineitä. Ei ole tärkeää, kumpi kirkonkellotarinoista on tosi. Kun puhutaan äänimuistoista, on haastavampaa tutkia miten ja milloin tietty ääni muistetaan, sillä muisto ei ole annettu itsestäänselvyys vaan kovan työn tulosta (vrt. Candau 1996, 5). Kun muistamme, esitämme jotakin itsestämme muille ja itsellemme (Fentress \& Wickham 1992, 7). Muisti toimii nykyisyydessä, muovaa mennyttä, jotta se olisi hyödyllinen meille tulevaisuudessa, filo- 
sofoi Candau (ibid. 31). Bissingenin kirkonkellotarinat pitävät yllä käsitystä kellojen suuresta merkityksestä kyläläisille.

\section{Aistit, muisti, paikat}

Filosofit kautta aikojen pohtineet, missä elimessämme muisti sijaitsee. Monissa uskonnoissa muisti ja korva tai kuuloelimet liitetään yhteen: korvahan yhdistää ihmiset spirituaalisesti. (Candau 1996, 23-24.) Myös useat etnografiat kertovat yhteisöistä, joissa muisti ja korva liittyvät toisiinsa. Ranskalainen Jacques Dournes on tutkinut vietnamilaista Jörai-heimoa, jonka seremonioissa - ainakin vielä kolmisenkymmentä vuotta sitten - vastasyntyneen Jörai-lapsen aistin herätetään puhaltamalla niihin inkiväärinjuuren ylitse. Kun kätilö puhaltaa lapsen korviin, hän herättää muistin. (op.cit. Fentress \& Wickham 1992, 37-38.) Tämä seremonia ilmaisee yhtäältä Jörai-käsitystä mielen ja ruumiin yhteydestä, toisaalta käsitystä yksilöiden yhteydestä sosiaaliseen ympäristöönsä. (ibid.)

Muistityyppejä on luokiteltu eri tavoin - kuuluisa on esimerkiksi Augustinuksen luokitus aistimuistiin, älymuistiin ja tunnemuistiin. Kirjailija Marcel Proust erotti toisistaan autenttisen muistin ja vapaaehtoisen muistin. Hänen mielestään haju ja makuaisti antavat meille autenttisia muistoja. Vapaaehtoinen muisti on taas järjen ja silmien muistia, joka paljastaa meille vain pintaa ilman totuutta. Luokituksista on siis pidetty, mutta nykyisin muistitutkijat ja neurobiologit ovat myös huomanneet, että eri muistityypit liittyvät siinä määrin toisiinsa, että niiden tiukka erittely on hyödytöntä. (Candau 1996, 125.)

Dollarissa tapasimme 88-vuotiaan David Grahamin, entisen lakimiehen, jolla on erinomainen aistimuisti ja samalla verbaalista lahjakkuutta ilmaista äänimuistoja taidokkaasti. Hän tiesi itsekin kykyjensä poikkeuksellisuuden ja mietti, miksi hän voi muistaa tarkalleen miltä lämpimät hyppynarun puukapulat tuntuivat 80 vuotta sitten, kun pieni tyttö antoi ne hänen käteensä. Hän pystyi kuvailemaan ääniä, joita hänen isänsä tärkätyt kaulukset päästivät 1920-luvulla; miltä kuulosti, kun lattiaa luutunnut palvelijatar läimäytti lähettipoikaa; millaisia erilaisia ääniä kuului pyykinpesupäivänä hänen lapsuutensa kotitalon keittiössä.

Paikat ovat muistojen kyllästämiä. Kaksikymmentäviisi vuotta sitten äänimaisematutkijat veivät David Grahamin eri paikkoihin Dollarissa ja nauhoittivat hänen äänimuistojaan (ks. Schafer 1977, 71-73). Yhdistimme tämän metodin ja arkkitehtikoulu ja äänentutkimuslaboratorio CRESSONissa kehitetyn 'paikkasidonnaisen kuuntelumenetelmän' (ks. Uimonen tässä julkaisussa): David Graham varustettiin mikrofonein ja kävelimme hänen mielireittiään Dollarissa. Paikkoihin liittyvät äänimuistot tulivat oivallisesti esiin. Muiston keriytyvät auki, kun ihminen käy dialogiin 
paikan kanssa. Eri aistein saadut havainnot, esimerkiksi näkymät, herättävät myös äänimuistot.

On kuitenkin pidettävä mielessä, että jos viemme ihmisen paikalla jossa hän kuuli asioita vuosia sitten, muistikuulokuva ei ole yksinkertainen aiemman kokemuksen replikaatio vaan se on myöhemmän elämänkokemuksen muovaama. Äänimuisti on - kuten muukin muistimme - dynaaminen ja plastinen.

Muistot ovat hyvin erityislaatuisia tutkimuksen lähdeaineistoja, ja tämä on otettava huomioon kun tutkimme kylien äänimaisemia ja identiteettejä. Kuinka tutkia kylien sosiaalista muistia äänen avulla? Sosiaalisen muistin teoreetikot Fentress ja Wickham ovat kysyneet: "Mitä on muisti? Metsästääkö sitä perhoshaavilla vai kyselykaavakkeella?"

Sensoristen muistikuvien metsästäjän haasteet ovat melkoiset. Äänimuistot eivät välttämättä sanallistu helposti. Kuten edellä mainitsin, tarinat ovat muistin luontaisia apuvälineitä. Ääniä voidaan myös soittaa ihmisille muistojen herättämiseksi. Monena päivänä tehdyt haastattelut ja ryhmähaastattelut saattavat tuottaa tulosta: muistot tönivät toisiaan hereille.

Äänimaisematutkijat puhuvat usein äänimaamerkeistä, yhteisön identiteeteille tärkeistä äänistä ja niiden säilyttämisestä. Mikä on tutkijan vastuu, kun hän ryhtyy puhumaan tiettyjen äänten säilyttämisen puolesta? Ainakin on syytä ymmärtää, että kun kylät, kansakunnat tai muut ihmisryhmät rakentavat identiteettejään, ne käyttävät hyvin vaihtelevia kriteerejä valitessaan säilytettäviä elementtejä menneisyydestään. Nämä elementit sitten useimmiten järjestetään siten, että niistä on hyötyä ryhmälle. Kuten antropologi Jonathan Friedman (1994, 12-13) on todennut: kaikella kulttuurisella luovuudella on motiivinsa, ja tietty elementtien kokonaisuus voi toimia ainoastaan silloin kun se saa kaikupohjaa kokonaisuuden luoneiden ihmisten tämän päivän kokemuksissa.

\section{Kirjalliset lähteet}

Bachelard, Gaston 1950. La dialectique de la durée. Paris: PUF.

Candau, Joel 1996. Anthropologie de la mémoire. Paris: PUF.

Fentress, James \& Chris Wickham 1992. Social Memory. Oxford: Blackwell Publishers.

Friedman, Jonathan 1994. Cultural Identity and Global Process. London: Sage.

Halbwachs, Maurice 1925 (uusi painos 1994). Les cadres sociaux de la mémoire. Paris: Albin Michel. Halbwachs, Maurice 1950. La mémoire collective. Paris: PUF.

Hyvärinen, Tero 2000. Nagu. Internet-sivuilla www.6villages.tpu.fi.

Järviluoma, Helmi 1991. Kenttä tutkijan asenteena. Kansanmusiikin tutkimus: Metodologian opas, toim. Pirkko Moisala). Helsinki: Sibelius-Akatemia ja VAPK-kustannus.

Järviluoma, Helmi 2000. Lesconil. Internet-sivuilla www.6villages.tpu.fi.

Pöyskö, Maru 1995. Siunattu melu ja pikku muu. Aspekteja navetan äänimaisemasta. Musiikkimaailmoja ja äänimaisemia, toim. Helmi Järviluoma. Kansanperinteen laitoksen julkaisuja J21; Virtain tutkimuksia 13. Tampere: Tampereen yliopisto. 
Roubin, Lucienne A. 1989. Le monde des odeurs. Paris: Méridiens, Klincksieck.

Schafer, R. Murray (toim.) 1977a. Five Village Soundscapes. \#4 in The Music of the Environment Series. Vancouver: A.R.C. Publications.

Schafer, R. Murray (toim.) 1977b. European Sound Diary. Vancouver: A.R.C. Publications.

Uimonen, Heikki 2000a. Dollar.Internet-sivuilla www.6villages.tpu.fi.

Uimonen, Heikki 2000b. Skruv. Internet-sivuilla www.6villages.tpu.fi.

Vikman, Noora 2000a. Bissingen. Internet-sivuilla www.6villages.tpu.fi.

Vikman, Noora 2000b. Cembra. Internet-sivuilla www.6villages.tpu.fi.

\section{Muut lähteet}

ÄPK HJ = Äänipäiväkirjat 2000, Helmi Järviluoma, kirjoittajan hallussa. 